\title{
Leprosy Work in the Madras Presidency.
}

\section{J. Josiah Joserh.}

$7 \mathrm{HE}$ seriousness and importance of the leprosy problem in the Madras Presidency were not realised till 1929, when Dr. Santra and his survey party demonstrated the high prevalence of the disease in certain areas. At the end of that year the Madras Government appointed Dr. J. Josiah Joseph to carry on the work Dr. Santra had initiated, chiefly in the direction of opening Leprosy Clinics and training Medical Officers. In 1930 he worked in East Godavari, Madura and South Kanara districts, trained Medical Officers and Health Officers, opened 15 clinics and inaugurated through the Public Health Department a rough survey of the Presidency which revealed about 56,000 cases. Realising the necessity for a generalised campaign throughout the Presidency the Government sanctioned the Group Leprosy Scheme. Six Group Leprosy Officers, Dr. Joseph being a Group Officer as well as the Chief Officer, were directed to organise the work throughout the Province within two years, the province being divided into six groups of districts. The Group Scheme having been found to be successful was extended in 1933 for another two years and again in 1935 for another two years. The Group Officers have so far trained about 500 Medical Officers in the up-to-date methods of classification, diagnosis and treatment, did propaganda work in villages, examined students for leprosy and have brought about 400 clinics into existence.

The following is a brief account of the activities connected with the campaign :-

1. Medical.-There are 12 leprosy asylums accommodating about 2,100 inmates, which is one hundredth of the total number of cases in the province and one twenty-fifth of the total number of cases treated in leprosy clinics in a year. The largest and most popular one is the Lady Willingdon Leprosy Settlement at Chingleput, which accommodates about 750 patients. The total cost of annually 
maintaining these institutions, partly with contributions from the Government and partly with contributions from other sources, is a little over three lakhs. The following is an abstract statement showing the work done in these institutions during 1933 and 1934.

\begin{tabular}{|c|c|c|c|c|c|c|c|c|c|c|}
\hline \multicolumn{5}{|c|}{ Total Treated During the Year. } & \multicolumn{5}{|c|}{ Total Discharged. } & \multirow[b]{2}{*}{ Total } \\
\hline Hindus & $\begin{array}{l}\text { Chris- } \\
\text { tians }\end{array}$ & $\begin{array}{c}\text { Mo- } \\
\text { hamm- } \\
\text { edans }\end{array}$ & Others & Total & $\begin{array}{l}\text { Symp- } \\
\text { tom } \\
\text { free }\end{array}$ & $\begin{array}{l}\text { Dis- } \\
\text { ease } \\
\text { arres- } \\
\text { ted }\end{array}$ & $\begin{array}{c}\text { Much } \\
\text { im- } \\
\text { proved }\end{array}$ & $\begin{array}{c}\text { Other- } \\
\text { wise }\end{array}$ & Died & \\
\hline $\begin{array}{l}1933 . \\
1753\end{array}$ & 1031 & 202 & 349 & 3335 & 144 & 172 & 157 & 993 & 118 & 1584 \\
\hline $\begin{array}{l}1934 \\
1789\end{array}$ & 833 & 186 & 334 & 3142 & 90 & 163 & 188 & 645 & 110 & 1196 \\
\hline
\end{tabular}

There are 408 out-patient clinics which are financed as follows :-

Government $\ldots \quad \ldots \quad \ldots \quad \ldots \quad 135$

Local Fund Board $\ldots . . .6 .199$

$\begin{array}{lllll}\text { Subsidised } & \ldots & \ldots & \ldots & 40\end{array}$

$\begin{array}{lllll}\text { Mission } & \ldots & \ldots & \ldots & 23\end{array}$

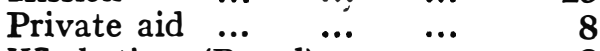

Whole-time (Board) $\cdots$

Four of these have been

closed for want of drugs.

It cannot be stated that all these clinics are working efficiently. The bi-weekly attendance at the various clinics is as follows :-

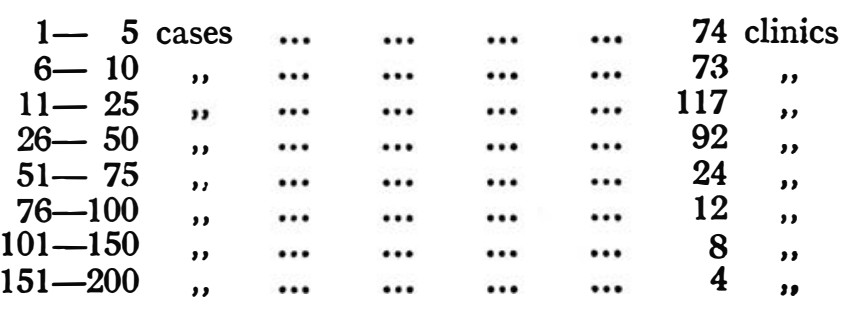

The total attendance at all these clinics for 1934 was 903,090 , compared with 695,295 for 1933 , and 380,050 in 1932.

From the available returns for 1934 the following results have been evaluated for 107 leprosy clinics :-

\begin{tabular}{|c|c|c|c|c|c|c|c|c|c|c|c|c|}
\hline \multicolumn{4}{|c|}{$\begin{array}{c}\text { Total cases treated more } \\
\text { than three months } \\
\end{array}$} & \multicolumn{6}{|c|}{$\begin{array}{l}\text { Results of cases treated more than } \\
\text { three months }\end{array}$} & & \multirow[b]{2}{*}{ 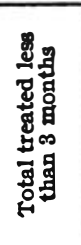 } & \multirow{2}{*}{ 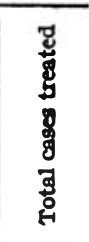 } \\
\hline 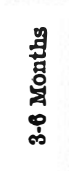 & 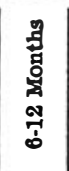 & 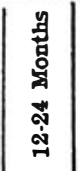 & 矛 & $\begin{array}{l}\text { 芯 } \\
\text { 罢 } \\
\text { 葛 } \\
\text { 否 }\end{array}$ & 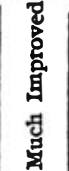 & 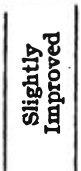 & 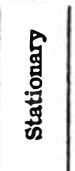 & 曾 & "ृ & 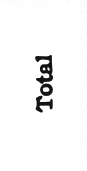 & & \\
\hline 712 & 663 & $|1626|$ & 7001 & 352 & 2348 & $\mid \overline{2839}$ & $\overline{1349}$ & 78 & 35 & 7001 & 7305 & \\
\hline
\end{tabular}


There are three whole-time leprosy clinics-one Government and two District Boards. The Government wholetime daily clinic is attached to the Government Royapuram Hospital where Medical Students and Medical Officers are trained, and where the Chief Leprosy Officer is conducting experiments with drugs tried by other leprosy workers.

The leprosy drugs used for injection are the creosoted hydnocarpus oil and the creosoted esters which are manufactured locally and supplied at 8 annas (7d.) and 1 rupee 4 annas (1s. 2 d.) a lb. respectively, and which are generally mixed in equal parts to reduce the viscosity of the one and the irritability of the other.

All the Medical Officers in charge of leprosy clinics carry on this work in addition to their dispensary or hospital duties and are not remunerated for this work as it forms one of their routine duties. But the medical practitioners in charge of the subsidised rural dispensaries are, in the case of Salem and South Arcot districts, given a remuneration on a sliding scale in the former district and a fixed quarterly honorarium in the latter district, as the pay they receive for their general dispensary work is small. In a few instances, this work is done by honorary doctors. It can be said with due deference to the medical officers already engaged in this campaign that encouragement by way of appreciation and remuneration will be a great incentive to them to take more interest in the campaign and to work whole-heartedly.

2. District Leprosy Councils.-The Leprosy conferences held in Calcutta at the beginning of 1933 and in Madras six months later, decided to have District Leprosy organisations to direct and co-ordinate the work in the districts, and a Central Provincial Leprosy Council for the Presidency. Accordingly, as many as 16 district Leprosy Councils have been formed and a Presidency Council will be formed very soon. Some of these Councils are devising ways and means to conduct the campaign along the most efficient lines and to raise money to meet the expenditure to be incurred thereby. In this connection mention must be made of the Salem District Council which is doing extremely good work, Mrs. A. H. A. Todd being solely responsible for this. It was she who organised the Council and has put it in a strong financial position by holding a very successful Leper Day, when 33,000 rupees was realised on that day alone. It was her sincerity and determination to rouse the civic conscience of the people of her district that made the appeal a great success. The District Boards have been 
requested to hand over their contributions for leprosy work to the District Councils, who have established the Leprosy Fund which is reinforced by subscriptions, donations, Leper Day collections, proceeds from benefit performances, etc.

Mention may also be made of the Saidapet Leprosy Association under the able leadership of Mrs. H. C. Buck. At the beginning of this year the Saidapet Leprosy Week was arranged, when lectures and exhibitions were given and competitions and sports were conducted, and on the Leper Day 700 rupees was collected. The members of this Association have completed the survey of the town, have examined all the dhobies, and licenced the healthy, have finished medical inspection of all the schools and are popularising the local leprosy clinic, which is in charge of their honorary medical officer. In the house to house survey conducted by men and lady social workers, 456 cases were detected in a population of 33,037 . The association now aims at following up the detected cases, observation of all the children and bettering the hygienic conditions which are now favouring the spread of the disease.

3. Clinic Committees.-In many treatment centres there are social committees to see to the needs of the clinic, to help the Medical Officer and to persuade and encourage patients to take regular treatment. The majority of these committees are able to attend to the needs of the clinic only, such as construction of leprosy sheds. In some places, individuals have constructed permanent clinic buildings, in some places the committees have raised subscriptions and have constructed pucca sheds, while some committees which could raise only small sums have constructed temporary sheds. Another activity in which some committees are interested is the feeding of indigent lepers and those who come from distant villages on the treatment days, with a view to attracting more patients to the clinics. Opinions differ in this matter, as the question is whether the patients should be attracted to the clinics by giving food or whether the patient should realise the necessity for and the efficacy of treatment. However, this activity has popularised many a clinic. One should remember that almost all the patients are daily labourers, and have to forego their wages on the days they attend the clinic, and that some of them have to walk a number of miles to and fro for the sake of treatment. If this activity could be carried on without interruption and if the social workers will give the necessary assistance, undoubtedly it will serve a very useful 
purpose. This depends greatly upon the interest and enthusiasm of the Medical Officer. In some places feeding is done by a number of charitable persons who take it by turns ; in some places provisions are collected from the public and are cooked and supplied to patients ; while in other places money is raised by subscriptions and benefit performances, and the provisions are bought, cooked and supplied. I may mention that owing to the enthusiasm of the Medical Officer and staff of the Local Fund Dispensary, Madurantakam, where about 200 cases are treated on each clinic day, more than half that number are fed on that day. The cost of feeding comes to 500 rupees per annum. This activity has been going on for more than a year and money was never found wanting.

4. Propaganda.-The Public Health Staff could not be depended upon for this work as they are fully engaged in other duties as vaccination, epidemics, etc., and the area of work allotted for each of them is very vast. Most of the propaganda work is done by the Group Leprosy Officers who are often directed by me to visit such of those clinics that are declining in popularity, and to do propaganda work in and around those centres to persuade patients to resort to treatment. Magic lantern lectures, distribution of leaflets and personal talks are the chief methods employed to do this work. Those infectious cases who should be isolated are advised either to go to the Leprosy Asylum or to isolate themselves in their own homes if facilities exist. Propaganda regarding the hygienic aspect of this work is not lost sight of, the people being told how a sanitary and hygienic mode of living can ward off leprosy.

The B.E.L.R.A. Leprosy Film was often shown in a few districts and was greatly appreciated by the people, who used to come in large numbers to see it. The Madras Public Health Department has also produced a leprosy film with a romantic plot wherein a young girl who had leprosy was treated by a doctor who finally married her. I have also revised the lantern slides to be more educative and fewer in number (30). The leaflets and posters have also been revised by me to be more appealing to the public.

5. School Medical Inspection.-The School Medical Inspection by special medical officers has been stopped owing to financial stringency, and the Government did well to put an end to that system of inspection as it was purely superficial. A new scheme should evolve whereby the students' health will be properly attended to and the special 
cases periodically examined. The Director of Public Instruction has permitted the Group Leprosy Officers to examine students in educational institutions for signs of leprosy and to give the necessary advice to the affected individuals. The following are the results of this inspection :-

\begin{tabular}{ll|r|r|r|r|r}
\hline & 1931 & 1932 & 1933 & 1934 & Total \\
\cline { 2 - 6 } Number of Schools examined & $\ldots$ & 3 & 24 & 103 & 179 & 309 \\
Number of Students examined & $\ldots$ & 600 & 3582 & 17276 & 23497 & 44955 \\
Number of Positive Cases & $\ldots$ & 1 & 20 & 191 & 271 & 483 \\
Number of Suspicious Cases & $\ldots$ & - & - & - & 20 & 20 \\
\hline
\end{tabular}

These students are advised to take treatment or to be under observation by the medical officer in charge of the nearest leprosy clinic, but most of them never cared to take their advice. It seems to me that it is very necessary that the school authorities should insist that the active cases are treated regularly and the others are sent periodically for observation by a trained doctor if they are to continue their studies, for one cannot say when a case in the quiescent phase will be stimulated into activity and become infectious. All leprosy experts agree that the disease in children up to a certain age must be attended to, and that if it does not develop beyond a certain age the chances of its working havoc in later years are very remote. This being so, it is very essential that students having the disease should be kept under careful treatment or observation.

6. Survey.-The Presidency was surveyed by the Public Health Department, in 1930, with a view to locating treatment centres, and about 56,000 cases were registered. As we expected that leprosy clinics would attract many early cases undetected by the Public Health staff, Medical Officers were directed to register all cases in detail that come to their notice. As the result of this about 120,000 cases have been registered. Many are the instances where the number of cases attending the clinic from a town or village was about five times the number of cases detected by the Health Staff in the same place. It is regrettable to state that some medical officers have omitted to give detailed addresses ot cases residing in towns, which omission would cause great difficulty in tracing them. Survey work and registration are also being done by the Group Leprosy Officers during their propaganda work.

It has often been suggested that the survey of a district 
will reveal the incidence in that area and give us an idea as to the places where the campaign should be centralised. No doubt, we may get a more definite idea of the incidence in that area, but I doubt whether it will serve a more useful purpose than the figures we have obtained and are obtaining, if they are well utilised, apart from making some deductions for purposes of epidemiology. One has also to consider the time, energy and money required for such a survey. Take for example the district of South Arcot with a population of about $2 \frac{1}{2}$ millions $(2,500,000)$. Working on the experience of Dr. Santra, Propaganda Officer for the B.E.L.R.A., with four sets of survey workers working in different directions, a rough survey of a number of villages having a population of 198,000 was completed in two months, which works out at 25,000 per month, or 1,250 a day (with 20 days to the month) for each set of workers. Having been one of the survey workers then, I can testify to the fact that this was not a house-to-house survey and that several adults were absent on account of their daily pursuits. Taking another instance, a complete house-to-house survey of Saidapet, with a population of 33,000 , was completed by one set of social and medical workers in about four and a half months, which works out at 7,000 a month. Hence a complete survey of South Arcot district, with a population of 2,500,000, can be done by four sets of workers as Dr. Santra's survey party did it, in 25 months, and as the Saidapet Leprosy Relief Association did it, in about 80 months. If a survey is done at all, it must be done thoroughly, in order to study the epidemiology and the exact incidence for comparison in future years.

After careful consideration of this subject of survey and the facilities and staff under me, I have decided to carry out centralised surveys, that is, surveys of areas around some specially selected clinics within a radius of five miles, which will include about 35 villages with a total population of about 35,000. The scheme will be :-

1. A few special treatment centres located in highly endemic areas, which are popular and where the registration work has been properly done, will be selected and worked out by each leprosy officer.

2. The cases registered at the special clinics and those detected by the leprosy officers and the Public Health staff are entered in village forms and a tabular statement showing the cases in each village belonging to the specified area drawn up as follows :- 


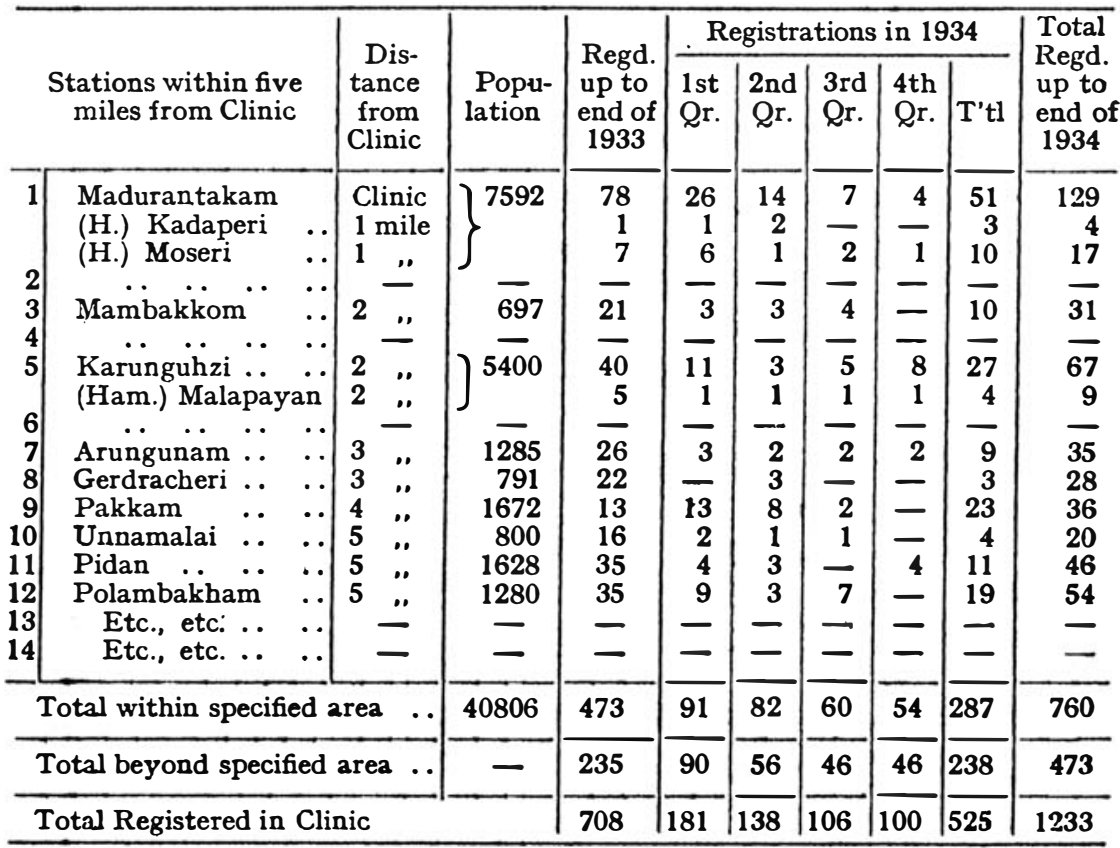

3. The villages in the specified area will be visited to verify the cases, detect new cases, examine contacts, especially children, trace source of infection, do propaganda work, carry on school inspections, and study economic, social, hygienic and other conditions in the village.

4. The names are then entered in permanent registers which will be used by social and medical workers for purposes of propaganda, etc.

This intensive survey-cum-propaganda work around each clinic will be of great value in the following ways : (a) incidence in the specified area can be approximately estimated; (b) clinics will become more efficient; (c) a leprosy or public health conscience will be cultivated in the minds of the villagers; $(d)$ incidence in one village can be compared with others in respect of age, sex, type, etc., and the epidemiology studied; $(e)$ periodical surveys will show increase or decrease and the effects of the campaign and the reasons for them.

There is a great tendency nowadays towards concentrating on the medical aspect of the leprosy problem. Undoubtedly, many patients have been benefited by treatment-the disease being arrested in several personsand consequently, if greater facilities are afforded for treatment, the results will be better. In the Madras Presidency there are 400 clinics and many more could be opened 
if finances permit. Now that the public are realising the efficacy of treatment, work should be directed towards making the existing clinics efficient, towards gauging the incidence of leprosy in highly endemic areas where treatment and propaganda can go hand in hand and towards prevention.

It cannot be denied that the three most important ways of eradicating leprosy are by (1) ridding the patient of his disease or arresting its activity and virulence ; $(2)$ increasing his natural defensive powers of resistance by improved diets and, (3) amelioration of his hygienic and personal conditions of living, which afford a favourable soil for the spread of leprosy. The first method depends upon the treatment and the regularity of the patient. The great disadvantage of the present-day method of treatment is the pain and the prolonged treatment, the effects of the treatment being manifested after a long time. There is also the scarcity of interested medical workers who could feel with the patients and encourage them to persevere in the treatment. On the other hand, the patients, like the rest of mankind, often expect a speedy cure or an early change in their lesions. Moreover, most of the patients are daily wage-earners, sometimes the only family bread earners, and a day's attendance at the clinic would mean deprivation of their income for the day. It is also to be noted that as the early stages of the disease do not cause any inconvenience or any disfigurement, the patients are indifferent to treatment.

The second method is almost impracticable under the present-day conditions of financial depression. In many villages the inhabitants are living a hand-to-mouth existence, with the result that any scourge of epidemics takes a heavy toll of lives. Many of the patients that attend the clinic show signs of inanition, and the fact that in clinics where feeding is done and more than 50 per cent. of the patients are fed, proves this. The economic aspect of this question cannot be touched upon at present except in the direction of advising the patients to use the available nutritious articles of diet in a better way.

The third method I still consider as the most important aspect upon which the success of the campaign will depend. It can be rightly stated that the improved conditions of living, the improved diet and a public health conscience, contributed far more towards the decline of leprosy in England than the stringent legislature and the compulsory segregation in leprosaria where it is very likely that most of the inmates would have been of the advanced 
non-infectious type. Hence, however small our efforts may be, and however few the facilities, the public health aspect of the leprosy problem must now be attended to. I do not advocate the idea of forming separate committees for leprosy, for tuberculosis, for rural reconstruction and so on, where the public health activity is so very similar. A health unit may be opened in an area with an efficient clinic as the nucleus of the leprosy campaign which is to be conducted on an extensive scale. To begin with, the area may be three miles in radius (about 28 square miles, enclosing about 20 villages) which may be extended in course of time. The villagers should realise that a general problem is being tackled in the interest and welfare of every individual in the village and their co-operation should be enlisted in the direction where their disabilities and wants lie. Their interest to stamp out leprosy should then be aroused. They will be given the names of all the affected individuals whom they ought to persuade to undergo outpatient or in-patient treatment, according to the needs of the case, and even arrange for isolation. Four or five such health units in the Presidency can be taken up and the activities compared and modified according to the results obtained and difficulties encountered. An intensive public health work in four or five places and centralised surveys in about 20 areas will be a very useful work to start with. At the same time there should be a proper supervision of all the clinics with a view to maintain their efficiency.

I would finally add a part of the report on Leprosy adopted by the Eleventh Meeting of the Research Workers' Conference of the Indian Research Fund Association, held in 1933 :-

"We consider that the time is now ripe for the Provincial Governments which have not already done so, to adopt a definite policy of leprosy work.

For the more efficient working of the anti-leprosy measures a Provincial Leprosy Board should be formed in each Province where leprosy is endemic. The Board should be chosen from representatives of the Medical and Health Departments, Mission to Lepers, British Empire Leprosy Relief Asssciation, and any other agency interested or engaged in leprosy work.

The Board will not as a rule be an executive body but principally advisory and initiatory. Its functions may include the following :

(a) Formulating a policy for the development of leprosy work in the Province. 


\section{Leprosy Work done in the Madras}

\begin{tabular}{|c|c|c|c|c|c|c|c|c|}
\hline & \multirow{2}{*}{\multicolumn{3}{|c|}{ Districts }} & \multirow{2}{*}{$\begin{array}{c}1931 \\
\text { Census }\end{array}$} & \multirow{2}{*}{$\begin{array}{l}\text { Health } \\
\text { Depart- } \\
\text { ment } \\
\text { Survey }\end{array}$} & \multicolumn{3}{|c|}{ Total New Cases } \\
\hline & & & & & & 1931 & 1932 & 1933 \\
\hline 1 & Gaujam $\quad \ldots$ & ... & $\cdots$ & 3337 & 5098 & 151 & 186 & 1100 \\
\hline 2 & Vizagapatam & ... & ... & 3347 & 4468 & 339 & 1906 & 1425 \\
\hline 3 & East Godaveri & ... & $\ldots$ & 1459 & 3330 & 4021 & 2352 & 1937 \\
\hline 4 & West Godaveri & ... & $\ldots$ & 2278 & 2468 & 375 & 562 & 2149 \\
\hline 5 & Kestna & ... & ... & 316 & 841 & 61 & 363 & 364 \\
\hline 6 & Gunhir & ... & $\ldots$ & 799 & 3233 & 178 & 264 & 728 \\
\hline 7 & Kurnool & ... & $\cdots$ & 267 & 384 & - & 99 & 171 \\
\hline 8 & Ananteipur & $\ldots$ & ... & 232 & 129 & - & 8 & 166 \\
\hline 9 & Bellary & $\ldots$ & $\ldots$ & 276 & 481 & 27 & 27 & 82 \\
\hline 10 & Cuddapah ... & $\ldots$ & $\ldots$ & 269 & 232 & 78 & 425 & 191 \\
\hline 11 & Clultoor & ... & $\ldots$ & 1144 & 1216 & 1768 & 1227 & 819 \\
\hline 12 & Wellore & $\ldots$ & ... & 414 & 1317 & - & 198 & 922 \\
\hline 13 & Madras & ... & $\ldots$ & 126 & - & 542 & 1120 & 2774 \\
\hline 14 & Chengleput & ... & $\ldots$ & 1799 & 2816 & 373 & 2340 & 2884 \\
\hline 15 & North Arcot & ... & $\ldots$ & 2776 & 5965 & 290 & 568 & 2467 \\
\hline 16 & South Arcot & ... & $\ldots$ & 4129 & 9050 & 2313 & 2297 & 9069 \\
\hline 17 & Salem & ... & ... & 1064 & 3665 & 1139 & 5977 & 7789 \\
\hline 18 & Trichinopoly & $\ldots$ & $\ldots$ & 1240 & 2076 & 84 & 103 & 2090 \\
\hline 19 & Tanjore & $\ldots$ & $\ldots$ & 1939 & 2700 & 59 & 1534 & 1485 \\
\hline 20 & Madura & $\ldots$ & $\ldots$ & 1624 & 2597 & 2283 & 2116 & 2046 \\
\hline 21 & Ramuad & $\ldots$ & ... & 852 & 969 & 69 & 297 & 760 \\
\hline 22 & Tinnevelly & ... & ... & 856 & 750 & 115 & 696 & 600 \\
\hline 23 & Coinbatore ... & ... & ... & 291 & 207 & 24 & 255 & 294 \\
\hline 24 & Malabar & ... & $\ldots$ & 1672 & 813 & 773 & 1095 & 1169 \\
\hline 25 & South Kanara & $\ldots$ & $\ldots$ & 710 & 666 & 268 & 284 & 722 \\
\hline 26 & Nilgiris & ... & $\ldots$ & 11 & 10 & - & - & - \\
\hline & Total ... & $\ldots$ & $\ldots$ & 32127 & 55481 & 15206 & 26963 & 44628 \\
\hline
\end{tabular}




\section{Presidency from 193 I to $19^{3} 5$}

\begin{tabular}{|c|c|c|c|c|c|c|}
\hline \multirow{2}{*}{$\frac{\text { Treated }}{1934}$} & \multirow{2}{*}{ Total } & \multicolumn{4}{|c|}{ Total Attendance at the Clinics } & \multirow{2}{*}{$\begin{array}{l}\text { No. of } \\
\text { Exist- } \\
\text { ing } \\
\text { Clinics }\end{array}$} \\
\hline & & 1931 & 1932 & 1933 & 1934 & \\
\hline 1422 & 3559 & 3999 & 14074 & 29771 & 32599 & 20 \\
\hline 2049 & 5719 & 3358 & 26308 & 27118 & 36929 & 21 \\
\hline 1707 & 10017 & 39780 & 30696 & 29739 & 29402 & 22 \\
\hline 2103 & 5189 & 4377 & 16013 & 35313 & 44590 & 13 \\
\hline 518 & 1306 & - & 6404 & 7474 & 11982 & 12 \\
\hline 907 & 2077 & 523 & 2718 & 7689 & 10296 & 15 \\
\hline 287 & 557 & - & 1033 & 2384 & 2544 & 10 \\
\hline 113 & 287 & - & 113 & 2768 & 2276 & 6 \\
\hline 68 & 204 & - & 140 & 2600 & 1704 & 3 \\
\hline 206 & 900 & 404 & 5223 & 2842 & 2600 & 7 \\
\hline 1651 & 5465 & 14269 & 13313 & 10612 & 17899 & 13 \\
\hline 853 & 1973 & - & 1937 & 17039 & 16159 & $\theta$ \\
\hline 3834 & 8270 & 7513 & 18404 & 38496 & 55194 & 9 \\
\hline 3971 & 9568 & 11963 & 43938 & 64180 & 101353 & 22 \\
\hline 4213 & 7538 & 3389 & 4099 & 30604 & 65364 & 26 \\
\hline 10192 & 23871 & 13420 & 18843 & 70973 & 157485 & 35 \\
\hline 4181 & 19086 & 23486 & 84829 & 167567 & 134511 & 40 \\
\hline 2878 & 5155 & 413 & 674 & 31442 & 45124 & 20 \\
\hline 1597 & 4675 & 2386 & 20365 & 30406 & 35412 & 11 \\
\hline 2564 & 9009 & 23939 & 32789 & 29955 & 41056 & 21 \\
\hline 348 & 1474 & 1190 & 2912 & 12503 & 13334 & 16 \\
\hline 709 & 2120 & 506 & 7866 & 10824 & 11047 & 12 \\
\hline 609 & 1182 & 466 & 3629 & 4368 & 9785 & 15 \\
\hline 2542 & 5579 & 11529 & 19796 & 24536 & 32580 & 16 \\
\hline 437 & 1711 & 2256 & 3932 & 4592 & 7240 & 9 \\
\hline 5 & 5 & - & - & - & 15 & 1 \\
\hline 49350 & 136147 & 169166 & 380050 & 695295 & 903050 & 404 \\
\hline
\end{tabular}


(b) Advising regarding future development of leprosy work planned by the local bodies in the Province.

(c) Co-ordinating leprosy work in the Province.

(d) By suitable propaganda through all favailable agencies, trying to create a background of public opinion without which anti-leprosy campaign cannot succeed.

(e) Raising funds for anti-leprosy campaign in the Province.'

(Vide B.E.L.R.A. Annual Report for the year 1933.)

I a m of opinion that the leprosy work in Madras Presidency progressed rapidly because of the close co-operation of the Government, the Local Boards and the public, as well as the willingness on the part of the medical officers to carry on this work as a part of their ordinary duties. The Government, ably assisted by the Provincial Leprosy Relief Committee constituted by them, strongly supported the leprosy campaign and continued its support even in the days of financial crisis. Success is ensured wherever governments take the leading parts in the campaign. 